\title{
FORMULATION AND EVALUATION OF FAST DISSOLVING TABLETS OF BUSPIRONE USING COPROCESSED SUPERDISINTEGRANTS
}

\author{
SHALLY SHARMA*, NIMRATA SETH, NARESH SINGH GILL \\ Department of Pharmaceutics, Rayat Institute of Pharmacy, Railmajra, Punjab, Department of Pharmaceutical Chemistry, Rayat Institute \\ of Pharmacy, Railmajra, Punjab \\ Email: shallysharma2731@gmail.com
}

Received: 14 May 2019, Revised and Accepted: 16 Jul 2019

\section{ABSTRACT}

Objective: The present study aims to formulate and evaluate Fast dissolving tablet of Buspirone, the drug that is used for management of anxiety, by direct compression method using various Super disintegrants.

Methods: Ten formulations (F1-F10) of fast dissolving tablets of Buspirone were prepared by using various Superdisintegrants. The prepared tablets were evaluated for hardness, friability, thickness, drug content uniformity, water absorption, wetting time, and disintegration time and in vitro dissolution study.

Results: Among all the formulations, F10 (containing $5 \mathrm{mg}$ of Coprocessed (CS: SSG 1:2) Superdisintegrants) was considered to be the best formulation, which released up to $98 \%$ drug in 20 min as compared to a marketed conventional dosage form which dissolves in approx 60 min. The results of stability study of formulation F10 after a period of two months indicated that the formulation was stable.

Conclusion: It was concluded that a fast-dissolving tablet of Buspirone containing various Superdisintegrants is better and effective to meet patient compliance.

Keywords: Buspirone, Superdisintegrants, Fast dissolving tablets, Croscarmellose sodium, Sodium starch glycolate

(C) 2019 The Authors. Published by Innovare Academic Sciences Pvt Ltd. This is an open-access article under the CC BY license (http://creativecommons.org/licenses/by/4.0/) DOI: http://dx.doi.org/10.22159/ijcpr.2019v11i5.35698

\section{INTRODUCTION}

The tablet is the most widely used dosage form existing today because of its convenience in terms of self-administration, compactness, and ease in manufacturing. However, geriatric, pediatric and mentally ill patients experience difficulty in swallowing conventional tablets, which leads to poor patient compliance [1]. To overcome these problems, scientists have developed innovative drug delivery system known as mouth dissolving/disintegrating tablets (ODTs) or fast-dissolving tablets [2]. The benefits of FDTs is to improve patients compliance, rapid onset of action, increased bioavailability and good stability which make these tablets popular as a dosage form of choice in the current market [3]. FDT tablets were prepared by using Superdisintegrants such as croscarmellose sodium and sodium starch glycolate which provide rapid disintegration of the tablet in mouth. Many techniques are provided to formulate ODT like direct compression, tablet moulding, spray drying, cotton candy process, mass extrusion and freeze-drying [4]. Of all these above-mentioned techniques, direct compression technique is most convenient and economical as it does not require any special manufacturing process [5].

Buspirone is an anxiolytic agent and a serotonin receptor agonist belonging to the azaspirodecanedione class of compounds. Its structure is unrelated to those of the benzodiazepines, but it has an efficacy comparable to diazepam. Buspirone is used in the treatment of generalized anxiety where it has advantages over other antianxiety drugs because it does not cause sedation (drowsiness) and does not cause tolerance or physical dependence [6].

\section{MATERIALS AND METHODS}

Buspirone was gift sample from Concern Pharma, Ludhiana (India). Croscarmellose sodium, Sodium starch glycolate and microcrystalline cellulose were obtained from DFE Pharma Ltd. All the chemicals and reagents used were of analytical or pharmacopoeial grade.

\section{Calibration curve of buspirone}

Calibration curve of Buspirone was prepared by using Sorensen buffer (pH 6.8) and Hydrochloride Acid buffer ( $\mathrm{pH}$ 1.2). The solution was scanned between 200-400 nm using UV-VIS 1700 (Shimadzu) double beam spectrophotometer at $240 \mathrm{~nm}$.

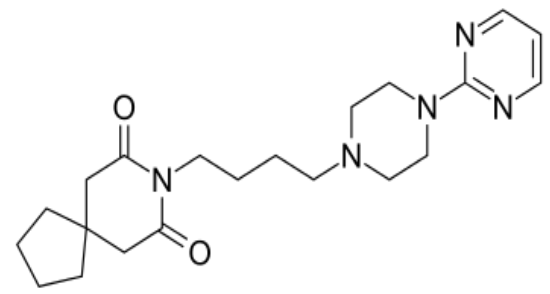

Fig. 1: Structure of Buspirone

\section{FT-IR spectroscopic analysis}

Drug polymer interactions were studied by FT-IR spectroscopy. 10 mg of Buspirone alone, a mixture of drug and polymer were weighed and mixed properly with potassium bromide uniformly. A small quantity of the powder was compressed into a thin semitransparent pellet by applying pressure. The IR-spectrum of the pellet from 450 $4000 \mathrm{~cm}^{-1}$ was recorded taking air as the reference and compared to study any interference.

\section{Preparation of Co-processed superdisintegrants}

The Co-processed Superdisintegrants were prepared by a solvent evaporation method. A blend of Crosscarmellose sodium and Sodium starch glycolate (in the ratio of $1: 1,1: 2$ and 2:1) was added to $10 \mathrm{ml}$ of isopropyl alcohol. The contents of the beaker $(250 \mathrm{ml}$ capacity) were stirred on a magnetic stirrer. The temperature was maintained between $65{ }^{\circ} \mathrm{C}$ to $70{ }^{\circ} \mathrm{C}$, and stirring was continued till most of isopropyl alcohol evaporated. The wet coherent mass was granulated through \#60-sieve. The wet granules were dried in a hot air oven at $60^{\circ}$ for $20 \mathrm{~min}$. The dried granules were sifted on \#60sieve and stored in an airtight container till further use. The 
prepared mixture was evaluated for flow properties and polymerpolymer compatibility studies such as FTIR study [7].

\section{Preparation of fast dissolving tablets of buspirone}

Fast dissolving tablets of Buspirone were prepared by direct compression method, using synthetic super disintegrant Croscarmellose sodium and Sodium starch glycolate in different ratios. Dextrose, Mannitol, Microcrystalline cellulose was used as excipients. The formula is shown in table 1.

Following steps were used in the preparation of fast dissolving tablets:
1. Weighed $10 \mathrm{mg}$ drug (Buspirone) along with super disintegrant (Croscarmellose sodium and sodium starch glycolate) in mortar.

2. Dextrose, Mannitol and Microcrystalline cellulose were added in a mortar, mixed with pestle and then added Magnesium stearate to it. These ingredients were then passed through sieve no 80 to remove impurities.

3. The blend was compressed into tablets on the tablet punching machine to obtain $100 \mathrm{mg}$ core tablet.

4. The fast-dissolving tablets were prepared and collected.

Table 1: Composition of fast dissolving tablets of buspirone

\begin{tabular}{|c|c|c|c|c|c|c|c|c|c|c|}
\hline FC (\%) & F1 & F2 & F3 & F4 & F5 & F6 & F7 & F8 & F9 & F10 \\
\hline Buspirone & 10 & 10 & 10 & 10 & 10 & 10 & 10 & 10 & 10 & 10 \\
\hline $\mathrm{CS}$ & 2 & - & 3 & - & 4 & - & 5 & - & - & - \\
\hline SSG & - & 2 & - & 3 & - & 4 & - & 5 & - & - \\
\hline Dextrose & 20 & 20 & 20 & 20 & 20 & 20 & 20 & 20 & 20 & 20 \\
\hline Mannitol & 36 & 36 & 35 & 35 & 34 & 34 & 33 & 33 & 35 & 33 \\
\hline MCC & 30 & 30 & 30 & 30 & 30 & 30 & 30 & 30 & 30 & 30 \\
\hline Magnesium Stearate & 2 & 2 & 2 & 2 & 2 & 2 & 2 & 2 & 2 & 2 \\
\hline Coprocessed CS: SSG(1:2) & - & - & - & - & - & - & - & - & 3 & 5 \\
\hline
\end{tabular}

${ }^{*} \mathrm{FC}=$ Formulation Component, ${ }^{*} \mathrm{CS}=$ Crosscarmellose sodium, ${ }^{*} \mathrm{SSG}=$ Sodium starch Glycolate, *MCC= Microcrystalline Cellulose

\section{Evaluation parameters}

\section{Precompression studies}

All the physical parameters namely, angle of repose, bulk density; compressibility index and Hausner's ratio were performed.

\section{Angle of repose}

The angle of repose gives an indication of the flowability of the substance. Funnel is adjusted such that the stem of the funnel lies 2 $\mathrm{cm}$ above the horizontal surface. The drug powder was allowed to flow from the funnel under the gravitational force till the apex of the pile just touched the stem of the funnel, so the height of the pile is taken as $2 \mathrm{~cm}$. Drawing a boundary along the circumference of the pile and taking the average of six diameters determined the diameter of the pile. These values of height and diameter were then substituted in the following equation:

$$
\text { Angle of } \operatorname{Repose}(\theta)=\tan ^{1}\left\{\frac{2 \mathrm{~h}}{\mathrm{~d}}\right\}
$$

Where h-Height of the pile and d-Diameter of the pile

\section{Bulk density}

Powder weighing $10 \mathrm{~g}$ was placed into $100 \mathrm{ml}$ measuring cylinder. Volume occupied by the powder was noted without disturbing the cylinder and bulk density is calculated by the following equation:

$$
\text { Bulk Density }=\frac{\text { Mass of bulk }}{\text { Volume of bulk drug }}
$$

\section{Tapped density}

It is the ratio of the total mass of powder to the tapped volume of powder.

The required quantity of powder blend was transferred in $100 \mathrm{ml}$ graduated cylinder which was operated for a fixed number of taps until the powder bed volume has reached a minimum Tapped density using the was calculated by formula given below:

$$
\text { Tapped density }=\frac{\text { Mass of bulk drug }}{\text { Volume of bulk drug on tapping }}
$$

\section{Compressibility}

It is a simple test to evaluate bulk and tapped density of a powder. The formula for Carr's index is as below:
$\%$ Compressibility $=\left\{\frac{[(\text { Tapped density })-(\text { Bulk density })]}{\text { Tapped density }}\right\} * 100$

\section{Hausner's ratio}

Hausner's of the drug is found out using the following formula $[8,9]$ :

$$
\text { Hausner Ratio }=\frac{\text { Tapped density }}{\text { Bulk density }}
$$

\section{Post-compression studies}

\section{Weight variation}

10 tablets were selected and weighed collectively and individually From the collective weight, the average weight was calculated. Each tablet weight was then compared with average weight to assure whether it was within permissible limits or not. Not more than two of the individual weights deviated from the average weight by more than $10 \%$ for $100 \mathrm{mg}$ tablets and none by more than double that percentage.

$$
\% \text { Weight Variation }=\frac{\text { Average weight- } \text { Individual weight }}{\text { Average weight }} \times 100
$$

\section{Hardness test}

Hardness of tablet is defined as the force applied across the diameter of the tablet in order to break the tablet. The hardness of the tablets was determined by diametric compression using Monsanto hardness tester

\section{Thickness}

The thickness was measured by placing tablet between two arms of the vernier calipers. Five tablets were taken and their thickness was measured.

\section{Friability test}

This test was performed to determine the effects of friction and shock. Pre weighed sample of 10 tablets was placed in the Roche friabilator and rotated at $25 \mathrm{rpm}$ for about $4 \mathrm{~min}$. The tablets were dedusted and reweighed, and the friability percentage was calculated. Compressed tablets should not lose more than $1 \%$ of the weight.

$$
\% \text { Friability }=\frac{[(\mathrm{W} 1-\mathrm{W} 2) 100]}{\mathrm{W} 1}
$$

Where, $\mathrm{W} 1=$ Weight of tablet before test, $\mathrm{W} 2$ = Weight of tablet after test 


\section{Wetting time}

The wetting time of the tablets was measured using a simple procedure. Five circular tissue papers of $10 \mathrm{~cm}$ diameter were placed in a Petri dish with a $10 \mathrm{~cm}$ diameter. Ten milliliters of water containing eosin, a water-soluble dye, was added to the Petri dish. A tablet was carefully placed on the surface of tissue paper. The time required for water to reach the upper surface of the tablets was noted as the wetting time. The wetting times were measured.

\section{Water absorption ratio}

A piece of tissue paper folded twice was placed in a small Petri dish (internal diameter $=6.5 \mathrm{~cm}$ ) containing $6 \mathrm{ml}$ of water. A tablet was placed on the paper and the time required for complete wetting was then measured. The water absorption ratio (R) was determined using the following equation.

$$
R=W a-W b / W a * 10
$$

Where $\mathrm{Wb}$ is the weight of the tablet before water absorption and $\mathrm{Wa}$ is the weight of the tablet after water absorption.

\section{Content uniformity}

Ten tablets of each batch were weighed and powdered. Aliquot of this powder containing Buspirone equivalent to $10 \mathrm{mg}$ of Buspirone was accurately weighed, suspended in approximately $50 \mathrm{ml}$ of $0.1 \mathrm{~N}$ $\mathrm{HCl}$ and shaken for $15 \mathrm{~min}$. Final volume was adjusted to $100 \mathrm{ml}$ with $0.1 \mathrm{~N} \mathrm{HCl}$ and filtered (Whatman No.1 filter paper). From this $10 \mathrm{ml}$ was diluted to $100 \mathrm{ml}$. The final volume was made by taking 2 $\mathrm{ml}$ of the above solution and diluted to $10 \mathrm{ml}$ with $0.1 \mathrm{~N} \mathrm{HCl}$.
Absorbance of this solution was recorded at $240 \mathrm{~nm}$ using UV/VIS spectrophotometer against a blank reagent.

\section{In-vitro disintegration test}

The in-vitro disintegration studies were carried out using a digital tablet disintegration test apparatus. One tablet was placed in each of the 6 tubes of the basket assembly and then disk was added to each tube. This assembly was then suspended in a 1-liter beaker containing water with its temperature being maintained at $37 \pm 2{ }^{\circ} \mathrm{C}$. The basket was then moved up and down through a distance of 5 to $6 \mathrm{~cm}$, at the frequency of 28 to 32 cycles per minute. The time required for complete disintegration of the tablet was recorded.

\section{In vitro dissolution test}

In vitro dissolution study is performed by using USP Type II Apparatus (Paddle type) at $50 \mathrm{rpm}$. The amount of drug dissolved is determined by a suitable analytical technique.

\section{Stability study}

The optimized formulation of FDTs is subjected to stability study as per ICH guidelines to assess their stability with respect to their physical appearance and release characteristic. The stability study was carried out at $40 \pm 2{ }^{\circ} \mathrm{C} / 75 \pm 5 \% \mathrm{RH}$ for two months [10-18].

\section{RESULTS AND DISCUSSION}

\section{Standard calibration curve of buspirone}

The standard calibration curve of Buspirone in Sorensen buffer $\mathrm{pH}$ 6.8) and Hydrochloride Acid buffer $(\mathrm{pH}$ 1.2) showed good correlation with regression value of 0.993 and 0.997 in fig. 2 and 3.



Fig. 2: Calibration curve of buspirone in sorensen buffer (pH 6.8)

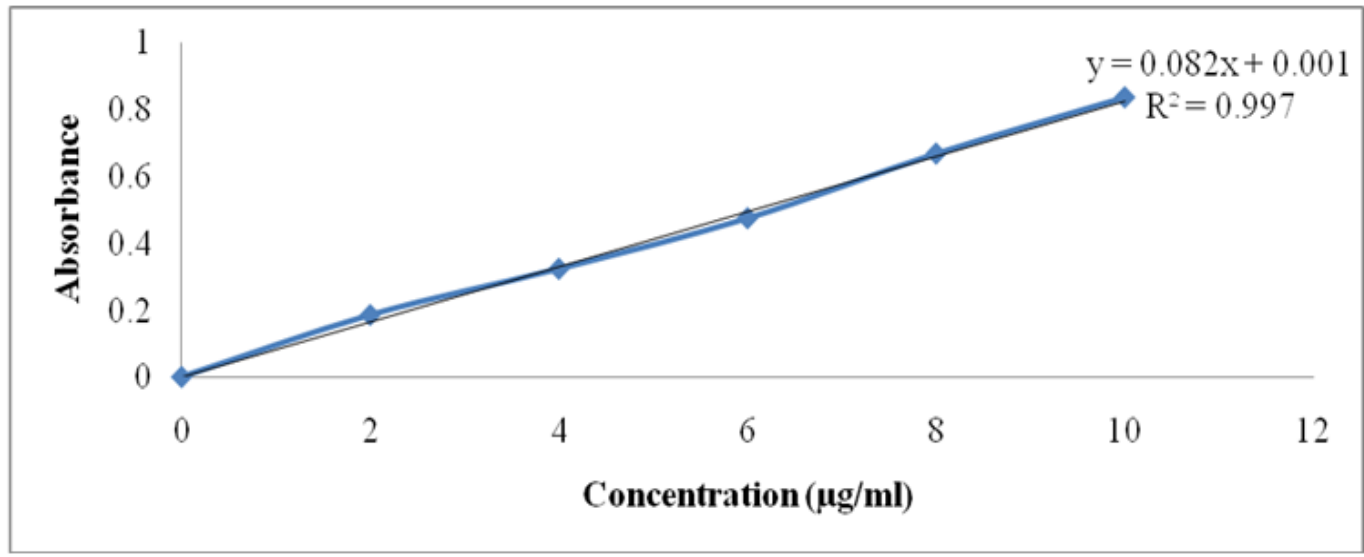

Fig. 3: Calibration curve of buspirone in Hydrochloride buffer (pH 1.2) 
FT-IR studies

The spectral data suggest that the major peaks for drugs are obtained as nearer value and there were no considerable changes in
IR peaks in all physical mixtures of drug and Superdisintegrants. This indicates that the drugs were molecularly dispersed in the polymers or in drug-loaded formulations thus thereby indicating the absence of any interactions as shown in fig. 4, 5 and 6.

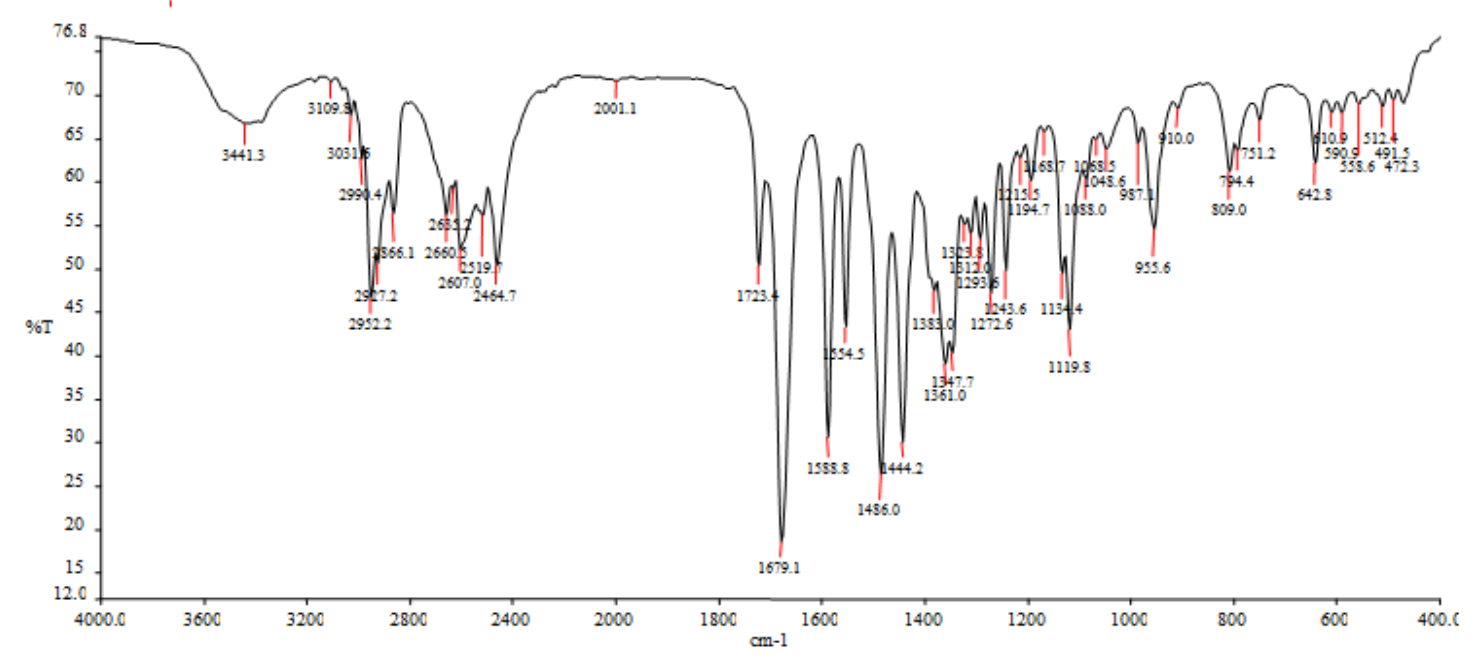

Fig. 4: FTIR graph for buspirone

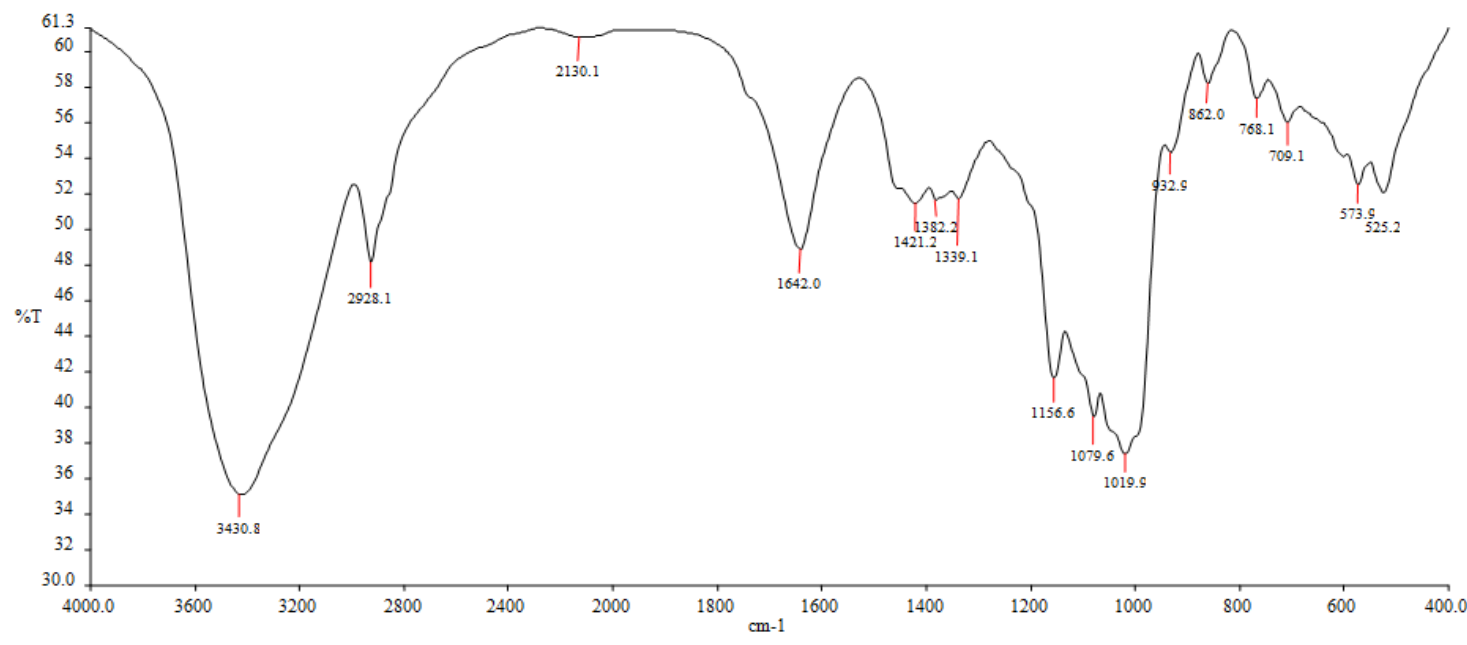

Fig. 5: FTIR spectra of co-processed superdisintegrants (Crosscarmellose sodium and sodium starch glycolate)



Fig. 6: FTIR spectra of buspirone and co-processed superdisintegrants 


\section{Pre-compression study}

\section{Evaluation of blend}

Physical properties such as bulk density, tapped density, percent compressibility index, Hausner's ratio, angle of repose were determined in table 2 for the prepared tablet blend. The tablet blend batches in which microcrystalline cellulose was used as the diluent, the angle of repose is between $27.5^{\circ}$ to $34.4^{\circ}$; this indicated the passable flowability.

This property may be attributed due to the presence of microcrystalline cellulose having filamentous particles as diluent. Also, Carr's index and Hausner's ratio were found to be in the range of $\leq 18$ and 1.08 to 1.17 respectively, indicating good flow and compressibility of the blends.

Table 2: Pre-compression parameters data

\begin{tabular}{|c|c|c|c|c|c|}
\hline $\begin{array}{l}\text { Formulation } \\
\text { component }\end{array}$ & $\begin{array}{l}\text { Bulk density } \\
\text { (g/cc) } \pm S D\end{array}$ & $\begin{array}{l}\text { Tapped density } \\
\text { (g/cc) } \pm \text { SD }\end{array}$ & $\begin{array}{l}\text { Carr's index } \\
(\%) \pm S D\end{array}$ & $\begin{array}{l}\text { Hausner's } \\
\text { ratio }\end{array}$ & $\begin{array}{l}\text { Angle of repose } \\
(\theta) \pm \text { SD }\end{array}$ \\
\hline F1 & $0.49 \pm 0.01$ & $0.56 \pm 0.02$ & $12.50 \pm 0.01$ & $1.14 \pm 0.02$ & $32.7 \pm 1.21$ \\
\hline F2 & $0.52 \pm 0.02$ & $0.61 \pm 0.01$ & $14.75 \pm 0.02$ & $1.17 \pm 0.01$ & $27.5 \pm 0.09$ \\
\hline F3 & $0.55 \pm 0.01$ & $0.61 \pm 0.03$ & $9.84 \pm 0.01$ & $1.11 \pm 0.03$ & $29.7 \pm 0.01$ \\
\hline $\mathrm{F} 4$ & $0.45 \pm 0.03$ & $0.52 \pm 0.01$ & $13.46 \pm 0.01$ & $1.16 \pm 0.05$ & $33.5 \pm 0.02$ \\
\hline F5 & $0.59 \pm 0.02$ & $0.67 \pm 0.01$ & $11.94 \pm 0.03$ & $1.14 \pm 0.06$ & $31.9 \pm 0.73$ \\
\hline F6 & $0.55 \pm 0.02$ & $0.62 \pm 0.02$ & $11.29 \pm 0.02$ & $1.13 \pm 0.04$ & $31.6 \pm 0.78$ \\
\hline F7 & $0.49 \pm 0.03$ & $0.57 \pm 0.01$ & $14.04 \pm 0.01$ & $1.16 \pm 0.03$ & $33.8 \pm 0.43$ \\
\hline F8 & $0.46 \pm 0.01$ & $0.51 \pm 0.03$ & $9.80 \pm 0.01$ & $1.11 \pm 0.02$ & $34.4 \pm 0.34$ \\
\hline F9 & $0.48 \pm 0.03$ & $0.53 \pm 0.01$ & $10.41 \pm 0.03$ & $1.12 \pm 0.01$ & $28.4 \pm 0.23$ \\
\hline F10 & $0.51 \pm 0.01$ & $0.55 \pm 0.02$ & $7.27 \pm 0.02$ & $1.08 \pm 0.02$ & $27.5 \pm 0.09$ \\
\hline
\end{tabular}

*All readings are in triplicate $(\mathrm{n}=3)$ and $\mathrm{SD}=$ Standard deviation

\section{Post-compression studies}

The data obtained of post-compression parameters such as hardness, thickness, friability, weight variation, amount of drug content, disintegration time and water absorption ratio are shown in table 3 and 4. Tablets obtained were of uniform weight (due to uniform die fill) with an acceptable variation. Hardness of the tablets was found to be $2.62 \pm 0.07$ to $3.06 \pm 0.03 \mathrm{~kg} / \mathrm{cm}^{2}$, indicating satisfactory mechanical strength. The thickness of tablets was found to be $3.11 \pm 0.03$ to $3.19 \pm 0.07 \mathrm{~mm}$. The result revealed that the tablets of all the formulations showed uniform thickness. In all the formulations, the friability values were less than $1 \% \mathrm{w} / \mathrm{w}$. The results of in vitro disintegration time of all the formulations were found to be within the prescribed limits and satisfied the criteria of fast dissolving tablets. The values were found to be in the range of 22 to $90 \mathrm{sec}$. The water absorption ratio for all formulations was found to be in the range of $81 \pm 0.08$ to $96 \pm 0.12 \%$.

Table 3: Evaluation parameters of fast dissolving tablets

\begin{tabular}{lllc}
\hline Formulation code & Weight variation $\mathbf{( m g )} \pm$ SD & Hardness $\mathbf{( k g / \mathbf { c m } ^ { 2 } ) \pm \text { SD }}$ & Thickness (mm) \pm SD \\
\hline F1 & $98.62 \pm 0.91$ & $2.73 \pm 0.08$ & $3.17 \pm 0.07$ \\
F2 & $97.58 \pm 0.81$ & $2.62 \pm 0.07$ & $3.12 \pm 0.08$ \\
F3 & $98.34 \pm 0.79$ & $2.93 \pm 0.12$ & $3.19 \pm 0.05$ \\
F4 & $101.3 \pm 0.90$ & $2.82 \pm 0.03$ & $3.15 \pm 0.19$ \\
F5 & $99.24 \pm 0.88$ & $2.84 \pm 0.02$ & $3.18 \pm 0.06$ \\
F6 & $97.78 \pm 0.93$ & $3.04 \pm 0.17$ & $3.14 \pm 0.09$ \\
F7 & $102.7 \pm 0.89$ & $2.98 \pm 0.06$ & $3.11 \pm 0.03$ \\
F8 & $98.94 \pm 0.96$ & $3.01 \pm 0.08$ & $3.16 \pm 0.04$ \\
F9 & $102.7 \pm 0.87$ & $2.97 \pm 0.06$ & $0.41 \pm 0.07$ \\
F10 & $99.61 \pm 0.91$ & $3.06 \pm 0.03$ & $0.43 \pm 0.06$ \\
\hline
\end{tabular}

*All readings are in triplicate $(n=3)$ and $S D=$ Standard deviation

Table 4: Evaluation parameters of fast dissolving tablets

\begin{tabular}{|c|c|c|c|c|}
\hline Formulation code & Water absorption ratio & Drug content uniformity & Wetting time (sec) & Disintegration time (sec) \\
\hline F1 & $90 \pm 1.25$ & $98.12 \pm 0.12$ & $97 \pm 0.52$ & $90 \pm 1.23$ \\
\hline $\mathrm{F} 2$ & $81 \pm 1.31$ & $96.31 \pm 0.16$ & $93 \pm 0.96$ & $92 \pm 0.72$ \\
\hline F3 & $82 \pm 0.18$ & $97.32 \pm 0.11$ & $90 \pm 0.56$ & $83 \pm 0.68$ \\
\hline $\mathrm{F} 4$ & $93 \pm 0.14$ & $95.82 \pm 0.13$ & $91 \pm 0.67$ & $87 \pm 0.57$ \\
\hline F5 & $89 \pm 0.12$ & $97.42 \pm 0.12$ & $63 \pm 0.71$ & $60 \pm 0.83$ \\
\hline F6 & $88 \pm 0.12$ & $98.33 \pm 0.14$ & $69 \pm 0.94$ & $62 \pm 0.74$ \\
\hline F7 & $84 \pm 0.09$ & $98.11 \pm 0.15$ & $49 \pm 0.61$ & $42 \pm 1.13$ \\
\hline F8 & $81 \pm 0.08$ & $93.41 \pm 0.14$ & $52 \pm 0.48$ & $46 \pm 0.48$ \\
\hline F9 & $89 \pm 0.13$ & $97.62 \pm 0.13$ & $33 \pm 0.54$ & $29 \pm 0.79$ \\
\hline F10 & $96 \pm 0.12$ & $98.39 \pm 0.12$ & $25 \pm 0.68$ & $22 \pm 0.82$ \\
\hline
\end{tabular}

*All readings are in triplicate $(\mathrm{n}=3)$ and $\mathrm{SD}=$ Standard deviation

\section{In vitro dissolution study}

The in vitro dissolution profile indicated faster and maximum drug release from formulations F10 in fig. 7 and 8. Formulation F10 shows 98\% respectively drug release at the end of $20 \mathrm{~min}$ when compared with another formula. The rapid drug dissolution might be due to the easy breakdown of particles due to porous structure formation rapid absorption of drugs into the dissolution medium. 
Table 5: In vitro release data of buspirone tablets

\begin{tabular}{|c|c|c|c|c|c|c|c|}
\hline Time (min) & $\mathbf{0}$ & 5 & 10 & 15 & 20 & 25 & 30 \\
\hline F1 & 0 & $17 \pm 0.58$ & $34 \pm 0.63$ & $55 \pm 0.59$ & $64 \pm 0.59$ & $81 \pm 0.47$ & $91 \pm 0.58$ \\
\hline $\mathrm{F} 2$ & 0 & $7 \pm 0.59$ & $14 \pm 0.41$ & $29 \pm 0.66$ & $41 \pm 0.43$ & $69 \pm 0.51$ & $84 \pm 0.64$ \\
\hline F3 & 0 & $11 \pm 0.61$ & $26 \pm 0.69$ & $42 \pm 0.63$ & $58 \pm 0.51$ & $73 \pm 0.67$ & $89 \pm 0.54$ \\
\hline $\mathrm{F} 4$ & 0 & $15 \pm 0.42$ & $28 \pm 0.44$ & $46 \pm 0.49$ & $63 \pm 0.66$ & $78 \pm 0.59$ & $90 \pm 0.43$ \\
\hline F5 & 0 & $19 \pm 0.68$ & $45 \pm 0.54$ & $66 \pm 0.61$ & $78 \pm 0.54$ & $86 \pm 0.48$ & $93 \pm 0.69$ \\
\hline F6 & 0 & $20 \pm 0.49$ & $43 \pm 0.53$ & $59 \pm 0.55$ & $72 \pm 0.49$ & $88 \pm 0.52$ & $96 \pm 0.52$ \\
\hline F7 & 0 & $23 \pm 0.63$ & $45 \pm 0.61$ & $76 \pm 0.47$ & $89 \pm 0.64$ & $97 \pm 0.69$ & - \\
\hline F8 & 0 & $25 \pm 0.52$ & $48 \pm 0.49$ & $71 \pm 0.59$ & $86 \pm 0.51$ & $93 \pm 0.42$ & - \\
\hline F9 & 0 & $30 \pm 0.69$ & $48 \pm 0.64$ & $69 \pm 0.53$ & $82 \pm 0.57$ & $97 \pm 0.55$ & - \\
\hline F10 & 0 & $32 \pm 0.46$ & $60 \pm 0.58$ & $90 \pm 0.41$ & $98 \pm 0.62$ & - & - \\
\hline
\end{tabular}

*All readings are in triplicate $(n=3)$ and $S D=$ Standard deviation

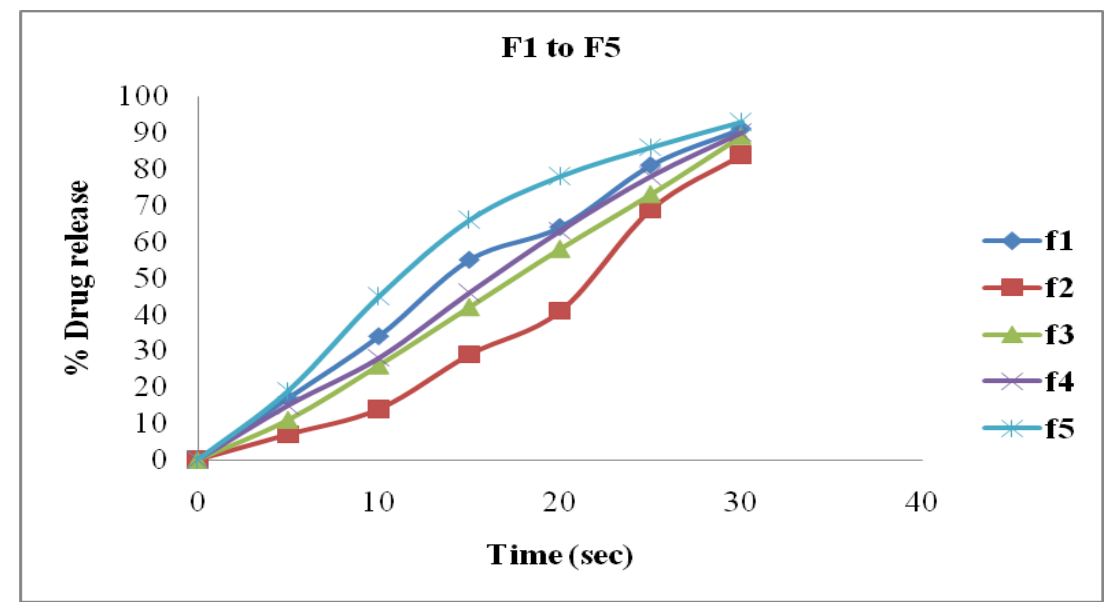

Fig. 7: Dissolution profile for F1, F2, F3, F4 and F5 formulations

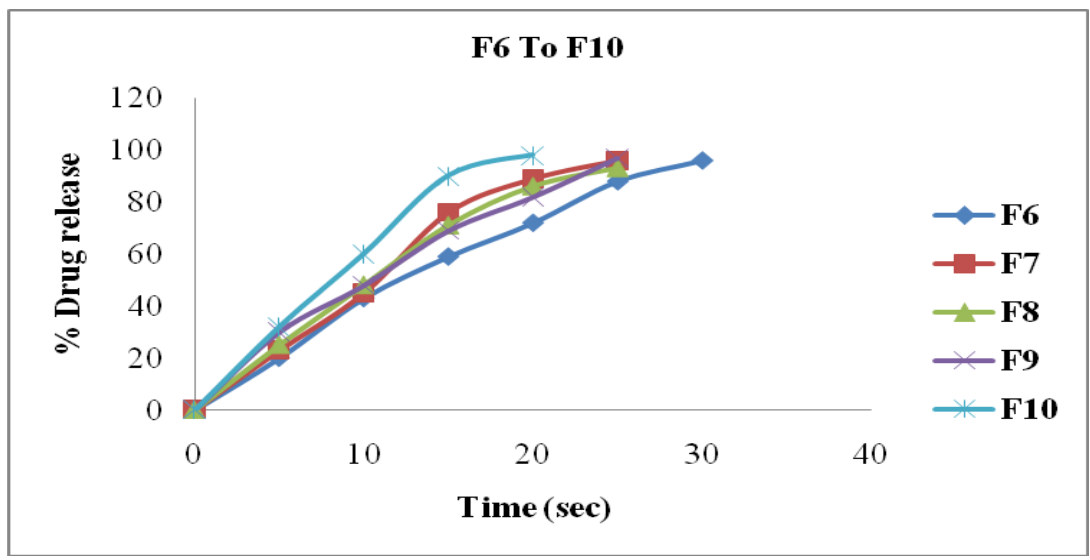

Fig. 8: Dissolution profile for F6, F7, F8, F9 and 10 formulations

\section{Stability study of formulations (F10)}

The stability study of formulation (F10) was carried out at $40 \pm 2$ ${ }^{\circ} \mathrm{C} / 75 \pm 5 \% \mathrm{RH}$ for two months. The tablets were wrapped in the aluminum foil and stored in a stability chamber at accelerated conditions. The drug content was checked at regular time intervals of $15,30,40$ and $60 \mathrm{~d}$ respectively and was evaluated for physical appearance. The results of drug content are shown in table 6 . There was no significant change in physical appearance, Drug content at the end of one month.

Table 6: Drug content during stability study

\begin{tabular}{lll}
\hline Time (days) & Accelerated conditions $\left(\mathbf{4 0 \pm 2}{ }^{\circ} \mathbf{C} / \mathbf{7 5} \pm \mathbf{5 \%} \mathbf{R H}\right)$ & Drug content \\
\cline { 2 - 3 } & Physical appearance & $98.39 \pm 0.12$ \\
\hline 0 & + & $97.84 \pm 0.14$ \\
5 & + & $97.04 \pm 0.04$ \\
10 & + & $96.32 \pm 0.19$ \\
20 & + & $95.72 \pm 0.06$ \\
30 & + & \\
\hline
\end{tabular}




\section{CONCLUSION}

In the present work, an attempt has been made to develop orally disintegrating tablets of buspirone. The IR spectra revealed that there was no interaction between disintegrants and drug. The result of physical parameter of all formulations by direct compression showed good flow property. Formulation F10 was the optimized formulation having least disintegration time as well as other parameters within acceptable range. In vitro release of optimized formulation of buspirone orally disintegrating tablets of F10 was found to be $98 \%$ drug release within $20 \mathrm{~min}$ with in vitro disintegration time being 22 sec. From this observation it was concluded that the formulated tablets of buspirone (F10) were superior and effective in achieving patient compliance.

\section{AUTHORS CONTRIBUTIONS}

All the author have contributed equally

\section{CONFLICT OF INTERESTS}

Declare none

\section{REFERENCES}

1. Hirani JJ, Rathod DA, Vadalia KR. Orally disintegrating tablets: a review. Trop J Pharm Res 2009;8:161-72.

2. Habib W, Khankari R, Hontz J. Fast-dissolve drug delivery systems. Critical Rev Ther Drug Carrier Systems 2000;17:61-72.

3. Sammour OA, Hammad MA, Megrab NA, Zidan AS. Formulation and optimization of mouth dissolve tablets containing rofecoxib solid dispersion. AAPS PharmSciTech 2006;7:E167E175.

4. Madan J, Sharma AK, Singh R. Fast dissolving tablets of aloe vera gel. Trop J Pharm Res 2009;8:63-70.

5. Shu T, Suzuki H, Hironaka K, Ito K. Studies of rapidly disintegrating tablets in the oral cavity using co-ground mixtures of mannitol with crospovidone. Chem Pharm Bull 2002;50:193-8.

6. https://www.drugbank.ca/drugs/DB00490. [Last accessed on 10 Mar 2019].

7. Gohel MC, Parikh RK, Brahmbhatt BK, Shah AR. Preparation and assessment of novel co-processed super disintegrant consisting of crospovidone and sodium starch glycolate: a technical note. AAPS PharmSciTech 2007;8:E63-E69.

8. Dobetti L. Fast-melting tablets: developments and technologies. Pharm Technol 2001;2:44-50.

9. Bi Y, Sunada H, Yonezawa Y, Danjo K, Otsuka A, IIDA K. Preparation and evaluation of a compressed tablet rapidly disintegrating in the oral cavity. Chemical and pharmaceutical bulletin 1996;44:2121-7.

10. Yeole PG, Galgatte UC, Babla IB, Nakhat PD. Design and evaluation of xanthan gum-based sustained release matrix tablets of diclofenac sodium. Indian J Pharm Sci 2006;68:185-9.

11. Arora P, Sethi VA. Orodispersible tablets: a comprehensive review. Int J Res Dev Pharm Life Sci 2013;2:270-84.

12. Banker GS, Anderson NR. Tablets. Theory Practice Industrial Pharm 1987;3:293-345.

13. Nawale RB, Mohite KP. Formulation and evaluation of domperidone orodispersible tablet. Tablet 2013;15:21.

14. Bandari S, Rajendar Kumar Mitta Palli, Ramesh Gannu, Yamsani Madhusudan Rao. Orodispersible tablets: an overview. Asian J Pharm 2008;2:2-6.

15. Nayak AK, Manna K. Current developments in orally disintegrating tablet technology. J Pharm Edu Res 2011;2:21.

16. Dufresne S, Leblond H, Chaunet M. Relationship between lumen diameter and length sterilized in the $125 \mathrm{~L}$ ozone sterilizer. Am J Infection Control 2008;36:291-7.

17. Indian Pharmacopoeia. $4^{\text {th }}$ ed. New Delhi: The Controller of Publications; 1996. p. 735-6

18. United State Pharmacopoeia. Convention. NF Asian edition; 2004. p. 74-5 